\title{
Safety of radiotherapy in patients with Behcet's disease: a case report and review of the literature
}

\author{
Dahui Ko ${ }^{1}$, Young Suk Kim², Yunseon Choi ${ }^{3, \text { Wu }}$ \\ ${ }^{1}$ Jeju National University College of Medicine, Jeju, Republic of Korea \\ ${ }^{2}$ Department of Radiation Oncology, Jeju National University Hospital, Jeju National University College of \\ Medicine, Jeju, Republic of Korea \\ ${ }^{3}$ Department of Radiation Oncology, Inje University Busan Paik Hospital, Inje University College of Medicine, \\ Busan, Republic of Korea
}

\begin{abstract}
Exaggerated acute and late toxicities following radiotherapy have been reported in patients with pre-existing connective tissue diseases, such as systemic lupus and scleroderma. Behcet's disease (BD) is a relapsing multisystem connective tissue disease characterized by vasculitis in the mucocutaneous, ocular, gastrointestinal, respiratory, neurologic, urogenital, articular, and cardiovascular systems. Data concerning the relationship between radiotherapy toxicity and BD are limited in the literature. Here, we report a case of lung cancer treated with radiotherapy (60 Gy) in a patient with BD. No severe radiation-induced toxicity was observed. Radiation-induced toxicity in patients with BD has also been discussed.
\end{abstract}

Key words: Behcet's disease, Neoplasms, Radiotherapy, Toxicity

\section{INTRODUCTION}

Behcet's disease (BD) is a relapsing inflammatory disorder of unknown etiology that manifests as recurrent oral aphthous ulcers, genital ulcers, uveitis, and skin lesions. ${ }^{1)}$ Most reports on severe toxicities, such as skin atrophy, skin necrosis, and fibrosis, after radiotherapy in patients with connective tissue diseases, involve patients with systemic lupus, rheumatoid arthritis, or scleroderma. ${ }^{2)}$ However, data

Received: July 23, 2021; Revised: August 20, 2021; Accepted: August 23, 2021

$\checkmark$ Correspondence to : Yunseon Choi

Department of Radiation Oncology, Inje University Busan Paik Hospital, Inje University College of Medicine, 75 Bokji-ro, Busanjin-gu, Busan 47392, Republic of Korea

Tel: 82-51-890-8606, Fax: 82-51-891-1754

E-mail: rtyoon@gmail.com concerning the relationship between radiotherapy toxicity and $\mathrm{BD}$ are limited in the literature. Herein, we describe the case of a patient with concomitant lung cancer and BD. Radiation-induced toxicity in patients with $\mathrm{BD}$ has also been discussed.

\section{CASE REPORT}

In February 2018, a 70-year-old man presented with a 3.5-cm nodule in the left upper lobe of the lung on chest radiography. The patient was a 50 pack-year current smoker with a medical history of hypertension, atrial fibrillation, intracerebral hemorrhage, and left middle cerebral artery infarction. The patient quit smoking in May 2018. Twenty-three years prior to presenting with the lung nodule, the patient 
underwent clipping surgery for a cerebral artery aneurysm. At that time, he was diagnosed with $\mathrm{BD}$, with symptoms of recurrent oral and genital ulcers, and knee arthritis and was prescribed oral colchicine. In addition to the chest X-ray, a computed tomographic scan of the chest revealed a $3.8-\mathrm{cm}$ malignant-looking mass in the left perihilar area and an enlarged lymph node in the left hilum. Surgery was recommended, but the patient refused.

In March 2019, the patient presented with dyspnea on exertion, cough, a 10-kg weight loss over the previous year, general weakness, and loss of appetite. The Eastern Coop-

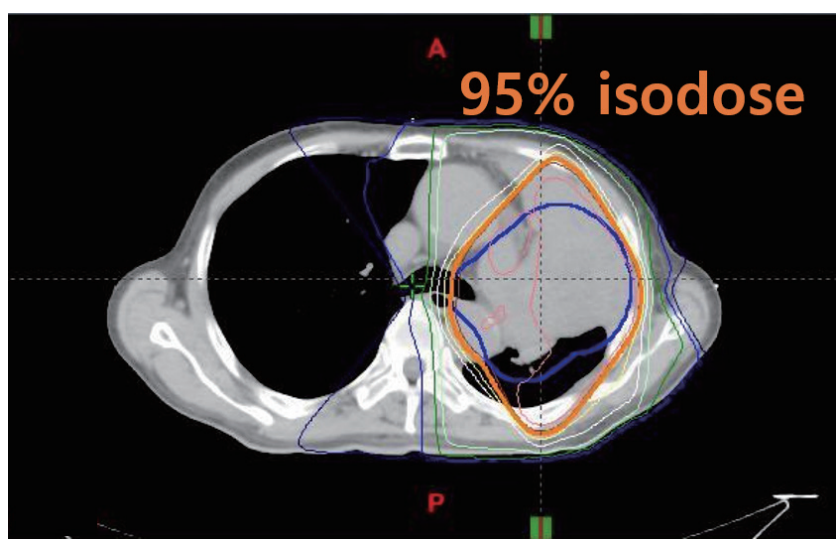

Figure 1. Isodose curves on an axial image. erative Oncology Group performance status score was 2 . Bronchoscopy revealed total obstruction of the left upper lobe main bronchus with a mass. Biopsy of the primary tumor revealed a poorly differentiated squamous cell carcinoma. Computed tomography of the chest revealed obstructive atelectasis and necrotizing pneumonia in the left upper lobe, enlarged lymph nodes in the left paratracheal area, hilum, and subcarina, and left malignant pleural effusion. Irregular atherosclerotic wall thickening in the aortic arch and abdominal aorta, penetrating ulcers at the aortic arch, and aneurysmal dilatation in the ascending aorta $(4.3 \mathrm{~cm})$ and descending thoracic aorta $(3.5 \mathrm{~cm})$ were also noted. The clinical stage was T4 N2 M1a. The patient had been treated with oral colchicine for $\mathrm{BD}$ at the time of radiotherapy. Oral and genital ulcers had been stable for 9 months before radiotherapy. Palliative radiotherapy for left upper lobe obstruction was recommended. The primary left hilar lesion received 60 Gy in 30 fractions (Figs. 1, 2). During radiotherapy, the patient experienced grade 1 esophagitis and a grade 1 skin reaction (redness on the anterior chest wall and back) (Table 1). One month after completion of radiotherapy, the primary left hilar lesion had decreased and the obstruction of the left upper lobe main bronchus had improved; however, lumbar spine (L1) metastasis and single 7-mm brain metastasis

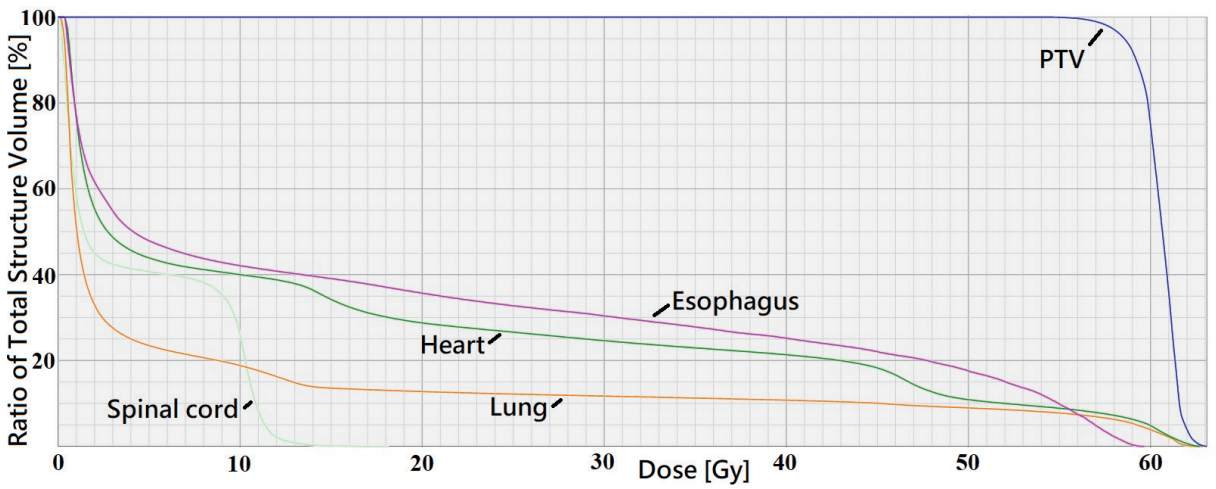

Table 1. Toxicity related to radiotherapy in our case
Figure 2. Dose volume histogram curves.

\begin{tabular}{lcccccccc}
\hline Age & Sex & Malignancy & Treatment & RT site & RT dose & Acute toxicity & Late toxicity & Comments \\
\hline 71 & $\mathrm{M}$ & Lung & RT & Mediastinum, & $60 \mathrm{~Gy} / 30 \mathrm{fr}$ & Esophagitis Gr 1, & No & $4 \mathrm{months} \mathrm{f/u}$ \\
& & & No chemotherapy & Lung & & Skin redness & 3DCRT \\
& & Brain & $35 \mathrm{~Gy} / 10 \mathrm{fr}$ & No & NA & Whole brain RT with SIB \\
& & & T12- L2 spine & $30 \mathrm{~Gy} / 10 \mathrm{fr}$ & No & NA & 3DCRT \\
\hline
\end{tabular}

M: male, RT: radiotherapy, NA: not applicable, f/u: follow-up, Gr: grade, 3DCRT: 3-D conformal radiotherapy, SIB: simultaneous integrated boost. 
Table 2. Toxicity related to radiotherapy in cancer patients with Behcet's disease

\begin{tabular}{|c|c|c|c|c|c|c|c|c|c|}
\hline Study & Age & Sex & Malignancy & Treatment & RT site & RT dose & Acute toxicity & $\begin{array}{l}\text { Late toxicity } \\
\text { (months) }\end{array}$ & Comments \\
\hline $\begin{array}{l}\text { Kaneko et al. } \\
(1974)^{8}\end{array}$ & 32 & M & $\begin{array}{l}\text { Nasal cavity } \\
\text { lymphoma }\end{array}$ & $\begin{array}{c}\mathrm{RT}, \\
\text { prednisolone, } \\
\mathrm{CT}\end{array}$ & Nasal cavity & $40 \mathrm{~Gy}$ & Tolerable & Tolerable & 5 months f/u \\
\hline $\begin{array}{l}\text { Harada et al. } \\
(1992)^{9}\end{array}$ & 43 & $\mathrm{~F}$ & $\begin{array}{l}\text { Intracranial } \\
\text { lymphoma }\end{array}$ & $\begin{array}{c}\mathrm{RT}, \\
\text { prednisolone }\end{array}$ & Brain & NA & Tolerable & Tolerable & $\begin{array}{l}\text { No problems } \\
\text { in daily life }\end{array}$ \\
\hline $\begin{array}{l}\text { Muramatsu et } \\
\text { al. }(1998)^{10}\end{array}$ & 47 & M & $\begin{array}{l}\text { Thigh, } \\
\text { sarcoma }\end{array}$ & Surgery, RT & Thigh & $66 \mathrm{~Gy}$ & NA & NA & 36 months f/u \\
\hline $\begin{array}{l}\text { Strohal et al. } \\
(1998)^{11}\end{array}$ & 21 & M & $\begin{array}{c}\text { Castleman's } \\
\text { disease }\end{array}$ & $\begin{array}{c}\mathrm{CT}, \mathrm{RT}, \\
\text { Interferon- } \alpha\end{array}$ & $\begin{array}{l}\text { Heart, neck, } \\
\text { mediastinum }\end{array}$ & $40 \mathrm{~Gy}$ & Tolerable & Tolerable & 44 months f/u \\
\hline \multirow[t]{6}{*}{$\begin{array}{l}\text { Cengiz et al. } \\
(2001)^{6}\end{array}$} & 47 & M & $\begin{array}{l}\text { Hodgkin's } \\
\text { disease }\end{array}$ & CT, RT & Mantle field & $40 \mathrm{~Gy}$ & $\begin{array}{c}\text { No increase in } \\
\text { severity or incidence }\end{array}$ & $\begin{array}{c}\text { Brachial } \\
\text { plexopathy (6) }\end{array}$ & $\begin{array}{c}\text { Pain in the left } \\
\text { upper arm }\end{array}$ \\
\hline & 54 & F & $\begin{array}{l}\text { Uterine } \\
\text { cervix }\end{array}$ & Surgery, RT & Pelvis & $50 \mathrm{~Gy}$ & $\begin{array}{c}\text { of acute radiation } \\
\text { morbidity }\end{array}$ & $\begin{array}{l}\text { Left ureteral } \\
\text { stricture (4) }\end{array}$ & $\begin{array}{l}\text { Percutaneous } \\
\text { nephrostomy }\end{array}$ \\
\hline & 44 & M & Bladder & CT, RT & Pelvis & $30 \mathrm{~Gy}$ & & No & \\
\hline & 25 & M & $\begin{array}{l}\text { Thigh, } \\
\text { sarcoma }\end{array}$ & $\begin{array}{c}\text { Surgery, CT, } \\
\text { RT }\end{array}$ & Thigh & 70 Gy & & $\begin{array}{c}\text { Skin necrosis } \\
\text { (6) }\end{array}$ & $\begin{array}{c}\text { Surgical } \\
\text { intervention }\end{array}$ \\
\hline & 46 & $\mathrm{~F}$ & $\begin{array}{l}\text { Uterine } \\
\text { cervix }\end{array}$ & $\begin{array}{l}\text { Surgery, } \\
\text { CCRT }\end{array}$ & Pelvis & 50.4 Gy & & No & \\
\hline & 43 & $\mathrm{~F}$ & Breast & $\begin{array}{c}\text { Mastectomy, } \\
\text { CT, RT }\end{array}$ & Chest wall & $50 \mathrm{~Gy}$ & & No & \\
\hline $\begin{array}{l}\text { Satolli et al. } \\
(2005)^{12}\end{array}$ & 67 & M & $\begin{array}{l}\text { Merkel cell } \\
\text { carcinoma }\end{array}$ & RT, CT & Skin, forearm & NA & NA & NA & $\begin{array}{c}\text { Died } 7 \text { months } \\
\text { after RT }\end{array}$ \\
\hline $\begin{array}{l}\text { Ono et al. } \\
(2005)^{13}\end{array}$ & 75 & $\mathrm{~F}$ & $\begin{array}{l}\text { Intracranial } \\
\text { lymphoma }\end{array}$ & $\begin{array}{c}\text { Surgery, } \\
\text { adjuvant RT }\end{array}$ & Brain & $50 \mathrm{~Gy}$ & Tolerable & Tolerable & 7 months f/u \\
\hline $\begin{array}{l}\text { Kaklamani et } \\
\text { al. }(2005)^{14}\end{array}$ & 44 & M & Lung & CT, RT & Brain & NA & NA & NA & \\
\hline $\begin{array}{l}\text { Lee et al. } \\
(2006)^{15}\end{array}$ & 40 & M & Colon & $\begin{array}{l}\text { Surgery, CT, } \\
\text { adjuvant RT }\end{array}$ & Abdomen & NA & No & No & 20 months f/u \\
\hline $\begin{array}{l}\text { Souabni et al. } \\
(2008)^{16}\end{array}$ & 46 & M & $\begin{array}{l}\text { Tonsillar } \\
\text { lymphoma }\end{array}$ & CT, RT & Tonsil, neck & 45 Gy & Tolerable & Tolerable & 4 years f/u \\
\hline $\begin{array}{l}\text { Meyer et al. } \\
(2008)^{2}\end{array}$ & 53 & M & Lung & $\begin{array}{l}\text { CCRT } \\
\text { (cisplatin, } \\
\text { etoposide) }\end{array}$ & Mediastinum & 64 Gy & $\begin{array}{c}\text { Esophagitis Gr 2, } \\
\text { bronchoesophageal } \\
\text { fistula }\end{array}$ & & $\begin{array}{l}5 \text { weeks after } \\
\text { completing RT }\end{array}$ \\
\hline $\begin{array}{l}\text { Chargari et al. } \\
(2009)^{5}\end{array}$ & 61 & $\mathrm{~F}$ & Breast & $\begin{array}{c}\text { Lumpectomy, } \\
\text { RT }\end{array}$ & Breast & $\begin{array}{c}44 \mathrm{~Gy} / 22 \\
\mathrm{fr}\end{array}$ & Epithelitis Gr 3 & & $\begin{array}{c}\text { Interruption of } \\
\text { RT }\end{array}$ \\
\hline \multirow[t]{2}{*}{$\begin{array}{l}\text { Ahn et al. } \\
(2010)^{17}\end{array}$} & 48 & $\mathrm{~F}$ & Rectum & $\begin{array}{l}\text { Surgery, } \\
\text { CCRT }\end{array}$ & Pelvis & NA & NA & NA & \\
\hline & 34 & M & Rectum & $\begin{array}{l}\text { Surgery, } \\
\text { CCRT }\end{array}$ & Pelvis & NA & NA & NA & \\
\hline \multirow[t]{2}{*}{$\begin{array}{l}\text { Na et al. } \\
(2013)^{4}\end{array}$} & 49 & $\mathrm{~F}$ & Breast & $\begin{array}{c}\text { Mastectomy, } \\
\text { CT, RT }\end{array}$ & Chest wall & NA & No & No & \\
\hline & 52 & M & Rectum & $\begin{array}{c}\text { Surgery, } \\
\text { CCRT }\end{array}$ & Pelvis & NA & No & No & \\
\hline
\end{tabular}


Table 2. Continued

\begin{tabular}{|c|c|c|c|c|c|c|c|c|c|}
\hline Study & Age & Sex & Malignancy & Treatment & RT site & RT dose & Acute toxicity & $\begin{array}{c}\text { Late toxicity } \\
\text { (months) }\end{array}$ & Comments \\
\hline & 53 & $\mathrm{~F}$ & Colon & $\begin{array}{l}\text { Surgery, } \\
\text { CCRT }\end{array}$ & Pelvis & NA & No & No & \\
\hline $\begin{array}{l}\text { Karatas et al. } \\
(2018)^{3}\end{array}$ & $38-56$ & $\mathrm{~F}$ & Breast & $\begin{array}{c}\text { Mastectomy/ } \\
\text { lumpectomy, } \\
\text { CT }(80 \%), \text { HT } \\
(70 \%), \text { RT }\end{array}$ & $\begin{array}{c}\text { Breast/chest } \\
\text { wall }\end{array}$ & NA & No & No & $\begin{array}{c}\text { No RT } \\
\text { complications } \\
\text { in } 10 \text { patients }\end{array}$ \\
\hline
\end{tabular}

RT: radiotherapy, CT: chemotherapy, NA: not applicable, CCRT: concurrent chemoradiotherapy, HT: hormone therapy.

in the right medial temporal lobe developed. Hippocampus-sparing whole brain radiotherapy with simultaneous integrated boost was applied at 35 Gy in 10 fractions for the right medial temporal lobe gross tumor and at $25 \mathrm{~Gy}$ in 10 fractions for the whole brain. The lumbar spine received 30 Gy in 10 fractions. No radiation-induced toxicities were observed. The patient did not undergo chemotherapy. In August 2019, 6 weeks after the completion of spine and brain radiotherapy, the patient died from obstructive pneumonia in the left upper lobe. This study was approved by the Institutional Review Board of the Jeju National University Hospital (IRB No. 2021-03-07).

\section{DISCUSSION}

In our case, there was no severe acute or late radiation-induced toxicity in the lung or mediastinum. Karatas et al. ${ }^{3)}$ reported no radiation-induced toxicity in 10 patients with breast cancer. $\mathrm{Na}$ et $\mathrm{al}^{4)}$ reported that radiotherapy was performed in three patients (breast, rectum, and colon) without complications (Table 2). On the other hand, several severe acute and late radiation-induced toxicity events have been reported in patients with $\mathrm{BD}^{2,5,6)}$ Chargari et al. ${ }^{5)}$ observed grade 3 epithelitis during adjuvant radiotherapy (44 Gy in 22 fractions) in a patient with breast cancer, which resulted in an interruption of radiotherapy. Meyer et al. ${ }^{2)}$ reported a bronchoesophageal fistula 5 weeks after the completion of definitive radiotherapy (64 Gy) and chemotherapy (cisplatin and etoposide) in a patient with lung cancer. They recommended considering screening for esophageal ulcers before initiating treatment for thoracic tumors in patients with BD. ${ }^{2)}$ Concurrent use of chemotherapy and high radiation dose may have contributed to the severe toxicity. Cengiz et al. ${ }^{6}$ reported three severe late toxicity reactions after radiotherapy in patients with BD (Table 2). A patient with Hodgkin's disease developed brachial plexopathy (pain in the left upper arm) 6 months after the completion of radiotherapy (40 Gy) to the mantle field. Another patient developed left ureteral stricture 4 months after the completion of postoperative radiotherapy (50 Gy) for cervical cancer. A third patient with a thigh mesenchymal tumor developed skin necrosis 6 months after the completion of postoperative radiotherapy (70 Gy).

The pathogenesis of BD remains unclear. A combination of infectious agents, immune disorders, environmental factors, and genetic factors may be related to $\mathrm{BD}{ }^{7)}$ Benderli Cihan et al. ${ }^{7)}$ recommended that during periods of exacerbation, $\mathrm{BD}$ patients receiving radiation treatment should be closely monitored for acute and chronic toxicity. In our case, recurrent oral and genital ulcers had been quiescent for 9 months before radiotherapy.

\section{CONCLUSIONS}

A limitation of our report is that the follow-up period after the completion of radiotherapy was only 4 months, which is too short to evaluate the effects of late toxicity. The total radiation dose and treatment volume can affect the level of toxicity. In our case, the total radiation dose was $60 \mathrm{~Gy}$, and most of the esophagus and mediastinum were excluded from the scope of the radiation treatment. These factors may have contributed to mild toxicity.

The relationship between BD and radiation-induced toxicity remains controversial. Several severe acute and late radiation-induced toxicity events have been reported. We need to be cautious when applying radiotherapy in patients with 
BD. Further studies regarding acute and late toxicity may be required to clarify the safety of radiotherapy in patients with $\mathrm{BD}$.

\section{REFERENCES}

1. Sakane T, Takeno M, Suzuki N, Inaba G. Behçet's disease. N Engl J Med 1999;341:1284-91.

2. Meyer J, Wahidi M, Shofer S, Evans J, Crawford J, Kelsey CR. Formation of a bronchoesophageal fistula following concurrent radiation and chemotherapy for lung cancer in the setting of Behçet's disease. J Thorac Oncol 2008;3:1361-2.

3. Karatas F, Sahin S, Aytekin A, Erdem GU, Ates O, Ozisik Y, et al. Behçet's disease and breast cancer: a case series study. J Cancer Res Ther 2018;14:1184-90.

4. Na SY, Shin J, Lee ES. Morbidity of solid cancer in Beḩet's disease: analysis of 11 cases in a series of 506 patients. Yonsei Med J 2013;54:895-901.

5. Chargari C, Kirova YM, Fourquet A, Campana F. Severe acute radiation-related skin toxicity in a breast cancer patient with Behçet's disease. Radiother Oncol 2009;91:139.

6. Cengiz M, Altundag MK, Zorlu AF, Güllü IH, Ozyar E, Atahan IL. Malignancy in Behçet's disease: a report of 13 cases and a review of the literature. Clin Rheumatol 2001;20:239-44.

7. Benderli Cihan Y, Sarigoz T. Which situations require attention during radiotherapy in patients with Behcet's disease-associated malignancy? J BUON 2016;21:522.

8. Kaneko H, Hojo Y, Nakajima H, Okamura A, Fukase M. Behçet syndrome associated with nasal malignant lymphoma--report of an autopsy case. Acta Pathol Jpn 1974;24:141-50.

9. Harada K, Ohtsuru K, Nakayama K, Takagi S, Sugita Y, Torigoe R. Intracranial primary malignant lymphoma following Behçet's disease--case report. No To Shinkei 1992;44:1029-33.

10. Muramatsu M, Kotake S, Yoshikawa K, Sasamoto Y, Matsuda H, Yamawaki S. The development of malignant rhabdoid tumor in a patient with Behçet's disease treated with ciclosporin. Graefes Arch Clin Exp Ophthalmol 1998;236:798-9.

11. Strohal R, Tschachler E, Breyer S, Uthman A, Simonitsch I, Tratting $\mathrm{S}$, et al. Reactivation of Behçet's disease in the course of multicentric HHV8-positive Castleman's disease: long-term complete remission by a combined chemo/radiation and interferon-alpha therapy regimen. Br J Haematol 1998;103:788-90.

12. Satolli F, Venturi C, Vescovi V, Morrone P, De Panfilis G. Merkelcell carcinoma in Behçet's disease. Acta Derm Venereol 2005;85:79.

13. Ono Y, Yamada M, Kawamura T, Ito J, Kanayama S, Katayama $\mathrm{Y}$, et al. Central nervous system malignant lymphoma associated with Behcet's disease. Case report. Neurol Med Chir (Tokyo) 2005;45:586-90.

14. Kaklamani VG, Tzonou A, Kaklamanis PG. Behçet's disease associated with malignancies. Report of two cases and review of the literature. Clin Exp Rheumatol 2005;23(4 Suppl 38):S35-41.

15. Lee JE, Sohn JW, Lee KH, Park YS, Kim KH, Choi JW, et al. Colon cancer in Behcet's disease. Yeungnam Univ J Med 2006;23:124-30.

16. Souabni L, Elleuch M, Amira C, Sellami S. Malignant lymphoma of the tonsil in a patient with Behçet's disease. Joint Bone Spine 2008;75:616-8.

17. Ahn JK, Oh JM, Lee J, Koh EM, Cha HS. Behcet's disease associated with malignancy in Korea: a single center experience. Rheumatol Int 2010;30:831-5. 